\section{A plea from Croatia}

SIR - Your argument that "the best hope for Yugoslavia" is something other than "six sovereign republics" (Nature 350, $176 ; 1991)$ has been frustrated by events. The majority of people in Slovenia, Croatia, Macedonia and Kosovo have voted freely for independence. The Federal Army has tried savagely to discipline' Kosovo, Slovenia and Croatia, also threatening Bosnia, Herzegovina and Macedonia. The option of Yugoslav federation is definitely dead.

Yugoslavia was the nineteenth-century vision of prosperity for a group of states historically wedged between the dying Turkish Empire on one side and antagonism within the Austro-Hungarian Empire on the other. Between 1918 and 1990, the idea proved a failure and certainly cannot be considered a solution for our problems on the eve of the twenty-first century. But that does not mean that inhabitants of these countries should kill each other and destroy what they have accomplished in nearly three-quarters of a century and in more than a thousand years of separate existence. The brutality of the Federal Army, protecting Serbian territorial interests, has resulted in hundreds of Croatian deaths, more than a third of them civilians, as well as the destruction of towns and villages and particularly churches, hospitals and schools. Vukovar, Osijek, Pakrac, Zadar, Šibenik, Gospić, Varaždin - some of the larger towns - have been bombed, while Dalj and Kijevo, like many other communities, have been levelled to the ground by heavy artillery. The airports in Croatia are closed, harbours and ports have been blockaded by the navy. We cannot travel freely either abroad or within the country.

How can we talk science when we are afraid for our lives, in shelters? Can we plan on ordering chemicals and experimental animals when children are being killed and libraries burned? We would not want to share the fate of Mr Riadh Dinha Francis and his family (Nature 351, $262 ; 1991)$, who were recognized on television by colleagues abroad and rescued from a Kurdish refugee camp by behind-the-scenes efforts. Nor do we want to be part of perhaps another DM1 million programme to assist researchers forced to leave their native land (Nature 351, 261; 1991).

Science has no homeland, but scientists do, and they feel strongly about their countries. Nikola Tesla (1858-1943), Lavoslav Ruzicka (1887-1976) and Vladimir Prelog (born 1906) are three Croatian scientists known worldwide, who made their careers abroad, but always considered Croatia their homeland.

As scientists and citizens of the world, NATURE - VOL $353 \cdot 17$ OCTOBER 1991 citizens. tries? Nature.

we despise frontiers and chauvinism of any kind. Why should we not collaborate with colleagues from Macedonia or Serbia? For scientific collaboration, it is not even necessary to live within the same country; to be forced to do that may even be counterproductive.

We believe that by alerting your public institutions and governments, as you have done in the case of fights for human rights in the Soviet Union, Chile, South Africa, Poland and Turkey, you could help us to stop the bloodshed and the destruction of our country and to establish the peace and economy indispensable for scientific work. Full recognition of Croatia as an independent and sovereign state is therefore urgent.

Our yearning for freedom is in line with that of every mature and selfconfident person and nation. As a civilized European nation, with 1,300 years of cultural tradition, we Croats have every right to build our future by ourselves - after the war. Our expert studies have shown that Croatia can fulfil the economic and other needs of all its

The term 'Balkanization' has been used in the world's media, including Nature. But we in Croatia strongly resent being called Balkans. This is not only geographical pedantry, but a result of the despicable flavour the word has acquired in the international vocabulary. "The Balkans' has meant a barrel of dynamite, and the place where the First World War started, but it is well known who was responsible for all the Balkan wars, the present war against Croatia included. But why should we not, with international help, remake the relationships in the Balkans into the type of relationships existing in the Scandinavian coun-

Briefly, Croats are a nation and Croatia a state, and we are not Balkans in the sense in which you used the word. We have the right to be free, to live in democracy and peace and to make our living the way we judge best. It is our misfortune that Serbia, our neighbour, cannot escape the mediaeval spirit of attacking its neighbours' territories. We may be mistaken in asking Europe and the rest of the world to understand the problem, but we do have the right to defend our homes and lives and the future of our children. At the same time, we hope we will survive as scientists and, some day, when our country is free and has recovered from the devastation, we shall still be able to publish in

Zagreb, Croatia

IVICA VUCAK ANTONIO JURETIC
OSI procedures

SIR - In her letter (Nature 353, 204; 1991) refuting allegations made earlier by Barbara Culliton concerning the procedures of the Office of Scientific Integrity (OSI), Dr Suzanne Hadley is very selective in her quotations from the Federal Register. She states that subjects of an OSI inquiry or investigation "are provided with an opportunity to review and comment on significant investigatory documents" but leaves out the remainder of that sentence: ". . . identified by OSI unless such disclosure would violate individual confidentiality or significantly impair the investigation". Indeed, in the same paragraph, there is this statement: "No opportunity is provided for subjects to confront and cross-examine other witnesses interviewed by OSI." Culliton is correct; these examples indicate why many scientists are aghast at the "starchamber' procedures of the OSI and at the feeble attempts to disclaim them.

Rockefeller University,

1230 York Avenue,

New York, New York 10021-6399, USA

\section{Human factors}

SIR - In your article "Secret Service as ultimate referee" (Nature 350, 553; 1991), you discussed the problem of apparent preference for particular digits in data recording. In addition to reports in the chemistry literature cited by Alan F. Thomas (Nature 352, 9; 1991), this phenomenon has been recognized in several sciences. In a classic paper by $G$. Udny Yule (J. R. statist. Soc. 90, 570$587 ; 1927)$ and a more recent review by D. A. Preece (Statistician 30, 31-60; 1981), examples are included from agriculture, anthropometry, demography, geography, meteorology and physics.

Where investigators are spontaneous, they may show preferences for 'round' numbers or particular odd or even numbers, while different objective rounding rules are recommended by different authorities or built in electronically into calculators or other devices. Biases may also arise in conversion of units or other arithmetic manipulations. As Preece points out, this variety limits the usefulness of chi-square or other formal significance testing of departures from a uniform distribution. While this is likely to be the natural null hypothesis where the possible range of values is much greater than the resolution of measurement, the most appropriate alternative hypothesis will usually have be guessed in each case after detailed scrutiny of the data.

NichOLAS J. COX

Department of Geography,

University of Durham,

Durham DH1 3LE, UK 